\title{
ANALYSIS OF LOCAL GOVERNMENT PERFORMANCE IN MANAGING DISTRIBUTION OF VILLAGE FUNDS (CASE STUDY IN KALIA VILLAGE, TALATAKO SUB-DISTRICT, TOJO UNA-UNA DISTRICT)
}

\author{
Riskawati \\ Tri Handayani Amaliah \\ Amir Lukum \\ Universitas Negeri Gorontalo
}

\begin{abstract}
This research aims to find out the capacity of the Kalia Village in managing the allocated village budget and the factors that supports and inhibits the village apparatus in managing the budget. The research directly involves in this research. Descriptive qualitative method is used in this research with the qualitative approach. This research located in Kalia Village of Talatako sub-district, district of Tojo Una-Una. The data collected through direct observation, interview, and documentation. The informants in this research is 13 people, comprises of 5 village apparatus, 2 members of village facilitator and 3 community members. The data are analyzed interactively through data reduction, data display, and conclusion drawing or verification. It reveals tha the village apparatus' capacity in managing the allocated village budget from planning, implementation, up to reporting and monitoring are less optimal. It is also found that majority of the village apparatus inadequate education level. In addition, the apparatus is also lacking in comprehending the tasks and functions of a village apparatus, as well as the technical skills of village apparatus hence the administrative requirements for allocated budget village are often submitted late that leads to late payment of allocated village budged.
\end{abstract}

Keywords: village government, village apparatus, management of allocated vilage budget

Indonesia terus mengupayakan peningkatan pelaksanaan pembangunan nasional agar laju pembangunan daerah serta pembangunan desa dan kota semakin seimbang dan serasi. Terbitnya Undang-Undang Nomor 6 Tahun 2014 tentang Desa, yang selanjutnya didukung Peraturan Pemerintah Nomor 43 Tahun 2014 Tentang Peraturan Pelaksanaan UndangUndang Nomor 6 Tahun 2014 Tentang Desa dan Peraturan Pemerintah Nomor 60 tentang Dana Desa yang Bersumber dari APBN menjadi sebuah titik awal harapan desa untuk bisa menentukan posisi, peran dan kewenangan atas dirinya. Harapan supaya desa bisa bertenaga secara sosial dan berdaulat secara politik sebagai fondasi demokrasi desa, serta berdaya secara ekonomi dan bermartabat secara budaya sebagai wajah kemandirian desa dan pembangunan desa berdasarkan Pancasila, Undang-Undang Dasar Negara Republik Indonesia Tahun 1945, Negara Kesatuan Republik Indonesia, dan Bhinneka Tunggal Ika.

Salah satu bentuk kepedulian pemerintah terhadap pengembangan wilayah pedesaaan adalah adanya anggaran pembangunan secara khusus yang dicantumkan dalam anggaran 
pendapatan dan belanja daerah untuk pembangunan wilayah pedesaan, yakni dalam bentuk alokasi dana desa. Inilah yang kemudian melahirkan suatu proses baru tentang desentralisasi desa diawali dengan digulirkannya alokasi dana desa yang diperkuat dalam Peraturan Pemerintah Nomor 60 Tahun 2014 tentang Dana Desa yang bersumber dari Anggaran Pendapatan dan Belanja Negara (APBN) Republik Indonesia.

Maksud pemberian alokasi dana desa adalah sebagai bantuan stimulan atau dana perangsang untuk mendorong dalam membiayai program pemerintah desa yang ditunjang dengan partisipasi, swadaya, gotong royong masyarakat dalam melaksanakan kegiatan pemerintahan dan pemberdayaan masyarakat. Dalam pelaksanaan kegiatan pengelolaannya melibatkan segenap aparat pemerintahan, baik di tingkat pusat maupun di tingkat daerah bahkan sampai di tingkat desa. Komponen atau aparat dimaksud hendaknya memiliki kemampuan yang optimal dalam pelaksanaan tugasnya. Tepatlah kiranya jika wilayah desa menjadi sasaran penyelenggaraan aktifitas pemerintahan dan pembangunan, mengingat pemerintahan desa merupakan basis pemerintahan terendah dalam struktur pemerintahan Indonseia yang sangat menentukan bagi berhasilnya ikhtisar nasional yang menyeluruh.

Mengingat kompleksnya aspek-aspek atau bidang yang hendak dibangun ditingkat pemerintahan desa dalam pelaksanaan tugasnya, maka salah satu aspek yang terlebih dahulu yang perlu dibangun adalah peningkatan kemampuan aparat desa dalam pelaksanaan tugastugas pemerintahan dalam pengelolaan alokasi dana desa, disamping memperkuat partisipasi kelembagaannya serta aspek-aspek lainnya. Mengingat kedudukan desa sebagai entitas pemerintahan mandiri, dan kepala desa sebagai pemegang kekuasaan pengelolaan keuangan desa beserta perangkat desa yang mendapat pelimpahan tugas tersebut mesti memiliki pemahaman dan keahlian dalam mengelola keuangan desa yang ditegaskan dalam UndangUndang Nomor 6 tahun 2014 yang menyatakan bahwa kepala desa/desa adat atau yang disebut dengan nama lain mempunyai peran penting dalam kedudukannya sebagai kepanjangan tangan negara yang dekat dengan masyarakat dan sebagai pemimpin masyarakat (Mustakim, 2015:11).

Hal tersebut sangat penting karena pemerintah desa beserta aparatnya adalah sebagai administrator untuk mengelola alokasi dana desa untuk aktifitas pemerintahan dan pembangunan kemasyarakatan maupun sebagai pembina ketentraman dan ketertiban di wilayah kekuasaannya. Karena itu, peran pemerintah desa demikian penting dan banyak menentukan maju mundurnya suatu unit pemerintahan. Oleh sebab itu, diperlukan aparat desa yang benar-benar mampu dan dapat bekerja sama dalam pelaksanaan tugas yang menjadi 
tanggung jawabnya. Dan keberadaan aparat desa dianggap lebih mengetahui secara pasti segala kondisi dan masalah yang ada diwilayahnya, maka input pada pemerintah kecamatan yang menyangkut berbagai keterangan dan informasi sangatlah dibutuhkan dalam pengambilan kebijaksanaan pembangunan secara menyeluruh.

Seperti pada Desa Kalia yang merupakan salah satu desa yang ada di Kabupaten Tojo Una-Una Provinsi Sulawesi Tengah dimana kemampuan aparatnya masih rendah merupakan bagian dari permasalahan yang ditunjukkan di lapangan. Dalam hal ini kemampuan aparat desa Kalia, masih belum memperlihatkan adanya kemampuan kerja dalam menjalankan tugas pokok dan fungsinya, diantaranya masih belum optimalnya aspek kelembagaan, sumberdaya manusia, maupun manajemen pemerintahan desa, serta kemampuan aparat desa Kalia yang belum memadai dalam penggunaan dan pengelolaan alokasi dana desa, sehingga kebutuhan masyarakat desa Kalia tidak sesuai dengan harapan masyarakat. Hal ini mencerminkan pula rendahnya kualitas aparat yang berdampak pada kurang efektifnya organisasi pemerintahan di Desa Kalia.

Beberapa fenomena atau gejala-gejala yang terjadi pada aparat di desa Kalia Kecamatan Talatako Kabupaten Tojo Una-Unat yaitu: 1). Masih kurangnya koordinasi antar aparat desa Kalia dengan Badan Permusyawaratan Desa dan Lembaga Permusyawaratan Masyarakat Desa, maupun masyarakat terkait dengan perencanaan, pelaksanaan, pengawasan dan pertanggungjawaban alokasi dana desa dimana antar aparat desa Kalia tidak saling memberikan informasi mengenai alokasi dana desa yang diterima oleh desa, yang menurut Ketua Badan Permusyawaratan Desa serta anggota, mengakui tidak mengetahui jumlah anggaran alokasi dana desa yang diterima; 2). Belum optimalnya fungsi Badan Permusyawaratan Desa dan lembaga permusyawaratan masyarakat desa dalam melaksanakan fungsinya masing-masing; 3). Belum optimalnya partisipasi masyarakat dalam mendukung perencanaan pembangunan; 4). Belum optimalnya penyediaan sarana prasarana teknologi informasi yang dapat meningkatkan kinerja pelayanan publik yang efektif dan efisien.

Berangkat dari uraian diatas diketahui bahwa kemampuan aparat Desa Kalia dalam mengelola alokasi dana desa belum berjalan secara optimal sehingga peneliti tertarik untuk melakukan penelitian tentang "Analisis Kemampuan Aparat Desa Dalam Pengelolaan Alokasi Dana Desa” (Suatu Studi di Desa Kalia Kecamatan Talatako Kabupaten Tojo Unauna).

\section{KAJIAN PUSTAKA}




\section{Kemampuan Aparat Desa}

Menurut Silalahi (2009:69) kemampuan adalah keterampilan dalam pelaksanaan pekerjaan atau kemahiran seseorang untuk menerapkan pengetahuan yang dimiliki dalam menjalankan fungsi atau tugas. Selanjudnya menurut Munir (2007:76) yang dimaksud dengan kemampuan dalam hubungan pekerjaan adalah suatu keadaan pada seseorang yang secara penuh kesungguhan, berdaya guna melaksanakan pekerjaan sehingga menghasilkan sesuatu yang optimal. Menurut Widjaja (2006:113) dalam bukunya yang berjudul administrasi kepegawaian berpendapat bahwa pegawai merupakan tenaga kerja jasmaniyah maupun rohaniah (mental dan pikiran) yang senantiasa dibutuhkan dan oleh karena itu menjadi salah satu modal pokok dalam usaha kerja sama untuk mencapai tujuan tertentu (organisasi). Kemampuan pegawai dapat dilihat dari beberapa dimensi yaitu: 1). Pendidikan, 2). Pelatihan, dan 3). Pengalaman kerja.

\section{Pemerintahan Desa}

Menurut Widjaja (2001:20) pemerintahan desa adalah kegiatan pemerintahan yang dilaksanakan oleh kepala desa dan badan permusyawaratan desa memiliki pemerintahan sendiri. Pemerintahan desa terdiri atas pemerintah desa (yang meliputi kepala desa dan perangkat desa) dan badan permusyawaratan desa. Dalam Undang-Undang Nomor 6 Tahun 2014 Tentang Desa dalam pasal 1 pemerintahan desa adalah penyelenggaraan urusan pemerintahan dan kepentingan masyarakat setempat dalam sistem pemerintahan Negara Kesatuan Republik Indonesia. Selanjutnya pemerintahan desa berdasarkan Peraturan Pemerintah Nomor 72 Tahun 2005 adalah penyelenggaraan urusan pemerintahan oleh pemerintahan desa dan badan permusyawaratan desa dalam mengatur dan mengurus kepentingan masyarakat setempat berdasarkan asal-usul dan adat-istiadat setempat yang diakui dan dihormati dalam sistem Pemerintahan Negara Kesatuan Republik Indonesia. Dan lebih jelasnya, pemikiran ini didasarkan bahwa penyelenggaraan tata kelola desa (disingkat penyelenggaraan desa), atau yang dikenal selama ini sebagai "pemerintahan desa" yaitu Kepala desa sebagai pelaksana kebijakan sedangkan badan permusyawaratan desa sebagai lembaga pembuat dan pengawas kebijakan (peraturan desa).

\section{Pengelolaan Alokasi Dana Desa}

Berdasarkan Peraturan Menteri Dalam Negeri Nomor 113 Tahun 2014 tentang Pengelolaan Keuangan Desa, bantuan langsung alokasi dana desa yang selanjutnya disebut 
alokasi dana desa adalah dana bantuan langsung yang dialokasikan kepada pemerintah desa digunakan untuk meningkatkan sarana pelayanan masyarakat, kelembagaan prasarana desa yang diperlukan serta diprioritaskan oleh masyarakat, yang pemanfaatan dan administrasi pengelolaannya dilakukan dan dipertanggung jawabkan oleh kepala desa. Selanjutnya dalam Peraturan Menteri Dalam Negeri Nomor 113 Tahun 2014 Tentang Pengelolaan Keuangan Desa, alokasi dana desa dikelola berdasarkan prinsip transparan, akuntabel, partisipatif, tertib, disiplin anggaran, dan penggunaannya dilakukan secara hemat, terarah dan terkendali. Kegiatan yang didanai oleh alokasi dana desa direncanakan dan dilaksanakan secara terbuka dan dibahas dengan melibatkan seluruh unsur elemen masyarakat dalam musyawarah desa dengan mengacu pada prioritas pembangunan yang tercantum dalam rencana pembangunan jangka menengah desa dan rencana kerja pembangunan desa. Pengelolaan alokasi dana desa sebagaimana dimaksud pada ayat (2) harus dapat dipertanggung jawabkan secara administratif, teknis, dan hukum.

Mekanisme pengelolaan keuangan alokasi dana desa merupakan bagian penting yang tidak dipisahkan dari pengelolaan keuangan desa dalam anggaran pendapatan dan belanja desa. Pengelolaan alokasi dana desa harus berpedoman pada prinsip -prinsip pengelolaan yang di atur dalam Peraturan Menteri Dalam Negeri Nomor 113 Tahun 2014 Tentang Pengelolaan Keuangan Desa, yang meliputi: 1). Perencanaan; 2). Pelaksanaan; 3). Petanggungjawaban; dan 4). Pengawasan alokasi dana desa.

\section{METODE}

Desa Kalia yang menjadi situs penelitian ini berlokasi di salah satu desa yang ada di Kecamatan Talatako Kabupaten Tojo Una-Una Propinsi Sulawesi Tengah. Desa Kalia terletak di pulau Talatako dengan jumlah penduduk 1.031 jiwa jiwa yang terdiri dari 537 jiwa laki-laki dan 494 Jiwa adalah perempuan. Desa Kalia merupakan salah satu yang memiliki kaitan dengan sejarah kerajaan pada masa lalu. Saat ini desa Kalia diusulkan oleh untuk menjadi salah satu calon Ibukota Kecamatan baru yang sementara ini diprakarsai.

Untuk mendapatkan informasi yang mendalam dari objek penelitian tentang fenomena yang diteliti, informan kunci dalam penelitian ini adalah aparat desa Kalia sebagai informan yang berjumlah 13 orang yang terdiri dari: 5 aparat Desa Kalia, 2 anggota BPD, 2 anggota LPMD, 1 pendamping desa dan 3 orang masyarakat. Penelitian ini merupakan jenis penelitian kualitatif. Penelitian ini bersifat naturalistic yang memfokuskan pada pengumpulan infomasi tentang keadaan atau realita yang sedang berlangsung yaitu dengan mengambarkan 
kemampuan aparat desa dalam pengelolaan alokasi dana desa di desa Kalia Kecamatan Talatako Kabupaten Tojo Una-una.

Penelitian yang dilakukan bersifat deskriptif-kualitatif dengan tehnik analisis interaktif. Adapun alasan penelitian kualitatif di atas dimaksudkan untuk lebih mementingkan proses pengumpulan data beragam dan disusun sebagai kekhususan untuk dikelompokkan bersama melalui proses pengumpulan data secara teliti serta saling berkaitan (bottom up grounded theory). Tekhnik analisis data yang digunakan adalah teknik analisis interaktif yang memiliki tiga komponen analisis yaitu reduksi data, sajian data dan penarikan kesimpulan atau verifikasi. Analisis ini dilakukan bersamaan dengan proses pelaksanaan di lapangan yang disusun secara lentur dan terbuka sesuai dengan kondisi yang sebenarnya dan lebih menekankan pada pendekatan kritik dalam merekonstruksi suatu peristiwa yang ada (Sutopo, 2006:42). Analisis data dalam penelitian ini dilakukan secara mendalam sebagai upaya mencari dan menata secara sistematis catatan hasil observasi, wawancara dan informasi lainnya untuk meningkatkan pemahaman peneliti tentang kasus yang diteliti.

\section{HASIL DAN PEMBAHASAN}

Dalam pelaksanaan pembangunan desa diperlukan aparat pemerintah desa yang berkemampuan, memiliki sikap pengabdian dalam menjalankan tugas. Bagi kepala desa dan perangkat-perangkat yang berhadapan langsung dengan masyarakat dibutuhkan kemampuan aparat pemerintah desa dalam pengelolaan alokasi dana desa untuk bisa meningkatkan kesejahteraan aparat pemerintah desa dan untuk pemberdayaan masyarakat. Dengan kemampuan yang memadai aparat pemerintah desa dapat melakukan berbagai hal dalam rangka mewujudkan hasil yang inginkan dan dengan kemampuan yang memadai pelaksanaan pembangunan dapat mencapai sasaran dan target yang telah ditentukan secara terarah, terpadu, berdayaguna serta berhasil. Guna mensejahterakan aparat desa maupun seluruh lapisan masyarakat sesuai dengan tujuan diberikannya alokasi dana desa.

Kemampuan aparat pemerintah desa akan dapat mengantisipasi dan menterjemahkan berbagai permasalahan program pembangunan sesuai tuntutan dan kebutuhan masyarakat dengan memanfaatkan sepenuhnya alokasi dana desa yang telah ada serta potensi dan sumber daya yang tersedia di desa. Alokasi dana desa merupakan salah satu aspek yang penting dari sebuah desa sebagai pendorong untuk menjalankan program-program dari pemerintahan. Oleh sebab itu, sangat diperlukan pembinaan dan pengelolaan alokasi dana desa kepada kepala desa dan perangkat-perangkatnya melalui suatu mekanisme pendidikan dan pelatihan 
yang dilakukan dari tingkat kecamatan maupun dari tingkat kabupaten. Berdasarkan hasil wawancara mendalam dengan para informan terkait dengan objek penelitian, setelah melalui proses analisis dan interprestasi, terkait dengan kemampuan aparat desa dalam pengelolaan alokasi dana desa tersebut dapat dilihat dari kemampuan aparat desa dalam perencanaan, pelaksanaan, pertanggungjawaban dan pengawasan alokasi dana desa.

\section{Tahapan Pengelolaan Keuangan Desa}

\section{Perencanaan}

Mekanisme tahap perencanaan pada pengelolaan alokasi dana desa di desa Kalia berawal dari pelaksanaan musyawarah desa. Perencanaan alokasi dana desa dilakukan dengan menjaring aspirasi dan kebutuhan masyarakat melalui musyawarah desa. Pelaksanaan musyawarah tersebut bertujuan untuk membahas perenacanaan anggaran pendapatan dan belanja desa, serta musyawarah rencana pembangunan desa (Musrembangdes) sehingga dihasilkan rencana penggunaan dana atau lebih dikenal dengan sebutan RPD. Dalam musyawarah yang dilaksanakan tercatat sebanyak 25 orang yang menghadiri pelaksanaan musyawarah tersebut yaitu yang dihadiri oleh kepala desa, perangkat desa, badan permusyawaratan desa, lembaga pemberdayaan masyarakat desa dan tokoh masyarakat dalam membahas berbagai sektor dan bidang di masing-masing dusun untuk menemukan kegiatan yang dapat didanai oleh alokasi dana desa sesuai dengan kondisi dan potensi desa.

Dari data yang diperoleh dan juga wawancara yang dilakukan peneliti dilapangan maka dapat diketahui bahwa kemampuan aparat desa Kalia dalam pengelolaan alokasi dana desa pada tahap perencanaan kurang optimal. Hasil penelitian menunjukan bahwa elemen-elemen yang terlibat dalam proses perencanaan telah berjalan, namun elemen masyarakat dan perwakilan masyarakat yang ada di BPD dan LPMD kurang aktif dalam pelaksanaan musyawarah desa. Hal ini menyebabkan perencanaan yang dibuat oleh aparat desa Kalia masih terbatas kepada memenuhi ketentuan dan belum menyentuh kepada esensi yang terkandung dari maksud partisipasi didalam proses perencanaan tersebut seperti yang tertuang dalam Peraturan Pemerintah No. 72 Tahun 2005 yang menjelaskan bahwa tujuan pelaksanaan ADD adalah (1) meningkatkan penyelenggaraan pemerintahan desa dalam melaksanakan pelayanan pemerintahan, pembangunan dan kemasyarakatan sesuai kewenangannya, (2) meningkatkan kemampuan lembaga kemasyarakatan di desa dalam perencanaan, pelaksanaan dan pengendalian pembangunan secara partisipatif sesuai dengan potensi desa, (3) 
meningkatkan pemerataan pendapatan, kesempatan bekerja dan kesempatan berusaha bagi masyarakat desa, dan (4) mendorong peningkatan swadaya gotong royong masyarakat.

Hal tersebut dapat dilihat dari hasil laporan mengenai tingkat partisipasi penduduk desa Kalia dalam pelaksanaan alokasi dana desa. Hal ini membuktikan bahwa partisipasi masyarakat sangat kurang untuk melaksanakan proses perencanaan sehingga tidak terbentuknya keterbukaan akses informasi bagi masyarakat terhadap kegiatan yang dilakukan di desa Kalia. Selain itu, aparat desa tidak memberikan keleluasaan bagi masyarakat untuk pengambilan keputusan yang mengakibatkan tidak terjadinya respon yang positif untuk mencapai kesejahteraan masyarakat. Sehingga, kemampuan aparat desa Kalia tidak dapat mencerminkan akuntabilitas didalam pengelolaan alokasi dana desa.

Ketidakserasian antara perencanaan dan pelaksanaan dalam pengelolaan ADD tersebut menurut Gafur (2011) disebabkan karena kurangnya kesadaran masyarakat terhadap kebijakan tersebut serta sikap apatis dari aparat pemerintah desa dan tidak adanya relevansi keberadaan Desa sebagai penyelenggaraan pemerintahan desa dalam perencanaan dan pelaksanaan Alokasi Dana Desa.

\section{Pelaksanaan}

Pelaksanaan alokasi dana desa menjadi bagian terpenting dalam suatu kegiatan atau pelaksanaan program, di desa Kalia dalam pengelolaan alokasi dana desa dibentuk sebuah tim yang bertugas untuk melaksanakan serta mengelola kegiatan yang dibiayai oleh alokasi dana desa.

Berdasarkan hasil penelitian menunjukan bahwa secara umum pelaksanaan alokasi dana desa di desa Kalia telah berjalan. Namun pelaksanaan kegiatan alokasi dana desa di desa Kalia Kecamatan Talatako Kabupaten Tojo Una-Una masih terdapat kendala yaitu keterbatasan pendidikan dan tanggungjawab aparat desa karena kurangnya pemahaman aparat desa dalam penggunaan anggaran dan juga kepala desa yang tidak memahami mekanisme pergeseran anggaran. Salah satu hasil temuan dalam dokumen anggaran pendapatan dan belanja desa yaitu masih terdapat belanja yang sudah di tuangkan dalam RAPBDesa namun tidak sesuai peruntukkan terutama pada bidang pembangunan desa, contohnya anggaran yang direncanakan untuk dilaksanakan sebagai pembuatan pos jaga (pos kambling) tidak dapat dilaksanakan karena sebagian biaya tersebut digunakan untuk pembelian pupuk. Selain itu jika dikaitkan dengan Peraturan Bupati Tojo Una-Una Nomor 2 Tahun 2014 tentang Pedoman Umum dan Petunjuk Teknis Pelaksanaan Alokasi Dana Desa yang menyatakan bahwa apabila terjadi pergeseran anggaran maka yang harus dilakukan oleh kepala desa 
bersama BPD yaitu dengan membuat Peraturan Desa tentang APBDesa sebagai dasar pelaksanaan. Seharusnya aparat desa Kalia membuat perubahan peraturan desa tentang perubahan anggaran pendapatan dan belanja desa karena terjadi pergeseran antar jenis belanja tersebut, dan tidak hanya membuat berita acara tentang pengalihan anggaran. Hal ini terjadi karena ketidak pahaman kepala desa sebagai pengguna anggaran dana alokasi dana desa atas mekanisme pergeseran anggaran.

Hal tersebut terjadi karena rendahnya pendidikan dan kurangnya keterampilan yang dimikili oleh aparat Desa Kalia dalam penyelesaian masalah dalam pengelolaan dana desa. Subroto (2009:81) menyatakan kurangnya jumlah dan kompetensi perangkat desa menimbulkan permasalahan dalam pertanggungjawaban administrasi keuangan ADD. Sehingga dari penjelasan tersebut maka kompetensi tersebut harus selalu diupayakan peningkatan secara berkelanjutan dengan memberikan pelatihan-pelatihan bagi aparat desa dalam pengelolaan keuangan desa.

3. Pertanggungjawaban

Pertanggungjawaban merupakan bentuk konsekuensi atas penggunaan dana publik yang dipercayakan kepada pemerintah desa. Pertanggungjawaban alokasi dana desa terintegrasi dengan pertanggungjawaban anggaran pendapatan dan belanja desa, sehingga bentuk pertanggungjawabannya adalah pertanggungjawaban pelaksanaan anggaran pendapatan dan belanja desa. Penanggungjawab operasional pengelolaan alokasi dana desa secara keseluruhan adalah kepala desa selaku ketua tim pelaksana desa.

Berdasarkan hasil penelitian dilihat dari aspek pertanggungjawaban pengelolaan alokasi dana desa yang diteliti bahwa kapasitas aparat desa Kalia dalam penyusunan pertanggungjawaban pengelolaan alokasi dana desa masih sangat rendah. Hal in dilihat dari bentuk pertanggungjawaban aparat pemerintah desa Kalia dalam membuat laporan pertanggunjawaban sebagai persayaratan pencairan alokasi dana desa, namun belum terjadi pertanggungjawaban dari aparat pemerintah desa Kalia terkait penggunaan dana alokasi dana desa secara langsung kepada masyarakat. Hal tersebut terjadi karena belum ada transparansi atau keterbukaan oleh aparat pemerintah desa Kalia sebagai pengelola dana alokasi dana desa kepada masyarakat dalam bentuk informasi penggunaan dana alokasi dana desa. Seperti dalam pelaksanaan kegiatan fisik yang didanai alokasi dana desa yang dilaksanakan oleh aparat desa namun sebagian besar tidak pernah menginformasikan kepada masyarakat tentang dana alokasi dana desa yang diterimanya. Hal tersebut bertentangan dengan ketentuan Peraturan Bupati Tojo Una-Una Nomor 2 Tahun 2014 tentang Pedoman Umum dan Petunjuk 
Teknis Pelaksanaan Alokasi Dana Desa bahwa kegiatan yang bersumber dari alokasi dana desa harus dipertanggungjawabkan secara langsung kepada masyarakat dan BPD.

Berkaitan dengan pertanggungjawaban dalam pengelolaan dana desa juga dapat secara umum masih menjadi permasalahan di Indonesia. Rahman (2012) menjelaskan rendahnya pertanggungjawaban administrasi keuangan ADD telah menjadi salah satu obyek korupsi oleh kepala/pegawai desa. Salah satu penyebab korupsi tersebut adalah kurangnya pengawasan dan keterbukaan dalam penyelenggaraan pemerintahan desa. Setyoko (2011) dalam hasil penelitiannya menunjukkan bahwa sebagian besar pemerintahan desa tidak berhasil mewujudkan akuntabilitas, baik akuntabilitas vertikal maupun horizontal. Sistem dan mekanisme pelaporan keuangan yang telah disusun dengan baik dan rinci oleh pemerintah kabupaten, ternyata tidak dapat dilaksanakan dengan baik oleh perangkat desa. Adapun kegagalan ini disebabkan oleh rendahnya kemampuan administratif perangkat desa, tidak adanya sanksi yang tegas dari pemerintah kabupaten terkait dengan ketidaktertiban administrasi keuangan ADD, serta masyarakat perdesaan yang kurang peduli terhadap persoalan akuntabilitas administrasi keuangan ADD.

\section{Pengawasan}

Pengawasan dilakukan terhadap jalannya pemerintahan dan pembangunan agar dalam pelaksanaannya tidak menyimpang dari rencana yang telah ditetapkan dan aturan yang berlaku berdasarkan terdahap pelaksanaan fisik maupun pengelolaan keuangan. Pengawasan pengelolaan alokasi dana desa secara fungsional yakni pengawasan oleh aparat pengawas atau satuan organisasi pemerintah Kabupaten Tojo Una-Una maupun pengawasan dari tingkat Kecamatan Talatako melalui pendamping desa dan pengawasan tersebut juga meliputi pengawasan langsung yang dilakukan oleh kepala desa kepada para tim pelaksana pengelolaan alokasi dana desa dan pengawasan tidak langsung yang berupa laporan tertulis yaitu lurat pertanggung jawaban alokasi dana desa.

Dari aspek pengawasan terlihat bahwa kurangnya pengawasan kepala desa yang berakibat pada keterlambatan pertanggungjawaban yang dibuat oleh bendahara desa, juga kepala desa tidak berpartisipasi aktif dalam mengoptimalkan pengawasan terhadapat kinerja aparat desa dalam membuat laporan pertanggungjawaban alokasi dana desa. Selain itu, pengawasan secara melekat yaitu pengawasan yang dilakukan oleh atasan langsung melalui struktur organisasi, bagan organisasi dengan rentang kendali yang tegas dengan pembagian tugas dan fungsi beserta uraian tugas pekerjaan yang jelas. 
Hasil penelitian ini menunjukan bahwa kemampuan aparat desa Kalia dalam pengelolaan alokasi dana desa pada tahap pengawasan dalam pengelolaan alokasi dana desa belum maksimal, dimana mulai dari perencanaan, pelaksanaan, pertanggungjawaban sampai pada pengawasan terutama yang menjadi kendala yaitu masalah kemampuan dan keterampilan dari aparat desa Kalia masih sangat kurang sehingga pencairan anggaran yang selalu terlambat, akibat dari terbatasnya kemampuan aparat desa Kalia sehingga apa yang telah direncanakan sebelumnya menjadi tertunda pelaksanaannya. Dengan demikian jelas bahwa pengawasan program pengelolaan alokasi dana desa yang dilakukan oleh kepala desa Kalia belum maksimal.

\section{Kendala Dalam Pengelolaan Keuangan Desa}

Selain itu ada pun kendala-kendala kemampuan aparat desa Kalia dalam pengelolaan alokasi dana desa yaitu rendahnya pendidikan sumber daya manusia dalam hal ini aparat desa Kalia maupun penduduk desa Kalia yang menjadi penghambat utama dalam pengelolaan alokasi dana desa, selain tingkat pendidikan aparat desa Kalia yang masih rendah faktor kesadaran/kemauan aparat desa juga masih kurangnya terhadapat tanggungjawab masingmasing aparat desa Kalia dalam pelaksanaan tugasnya masing-masing dan kendala lainya seperti pengawasan dari tingkat kabupaten/kecamatan masih kurang. Sehingga kedepannya dibutuhkan bimbingan kepada aparat desa Kalia secara maksimal dari pemerintah kecamatan maupun kabupaten untuk memberikan pendidikan dan pelatihan terhadap aparat desa Kalia dalam pengelolaan alokasi dana desa sehingga aparat desa Kalia mengetahui segala sesuatunya yang berkaitan dengan pengelolaan alokasi dana desa untuk pembangunan desa dan pemberdayaan masyarakat desa.

\section{SIMPULAN DAN SARAN}

Berdasarkan hasil dan pembahasan yang telah dilakukan, peneliti menarik kesimpulan temuan terkait dengan kemampuan aparat desa dalam pengelolaan alokasi dana desa diperoleh selama melakukan penelitian. Pertama, kemampuan aparat desa dalam perencanaan alokasi dana desa dapat dilihat dalam perencanaan atas alokasi dana desa oleh aparat pemerintah desa Kalia terlihat sudah berjalan namun partisipasi masyarakat sangat kurang untuk melaksanakan proses perencanaan sehingga tidak terbentuknya keterbukaan akses informasi bagi masyarakat terhadap kegiatan yang dilakukan di desa Kalia; Kedua, kemampuan aparat desa dalam pelaksanaan alokasi dana desa di desa Kalia Kecamatan 
Talatako Kabupaten Tojo Una-Una masih terdapat kendala yaitu keterbatasan pendidikan dan tanggungjawab aparat desa karena kurangnya pemahaman aparat desa dalam penggunaan anggaran dan juga kepala desa yang tidak memahami mekanisme pergeseran anggaran; Ketiga, kemampuan aparat desa dalam pertanggungjawaban alokasi dana desa terlihat bahwa kapasitas aparat desa Kalia dalam pertanggungjawaban pengelolaan alokasi dana desa kepada masyarakat yang masih kurang. Hal tersebut terjadi karena belum ada transparansi atau keterbukaan oleh aparat pemerintah desa Kalia sebagai pengelola dana alokasi dana desa kepada masyarakat dalam bentuk informasi penggunaan dana alokasi dana desa; Keempat, kemampuan aparat desa dalam pengawasan alokasi dana desa terlihat bahwa dari aspek pengawasan terlihat bahwa kurangnya pengawasan kepala desa yang berakibat pada keterlambatan pertanggungjawaban yang dibuat oleh bendahara desa, juga kepala desa tidak berpartisipasi aktif dalam mengoptimalkan pengawasan terhadapat kinerja aparat desa dalam membuat laporan pertanggungjawaban alokasi dana desa.

Selain itu ada pun kendala-kendala kemampuan aparat desa Kalia dalam pengelolaan alokasi dana desa yaitu rendahnya pendidikan sumber daya manusia dalam hal ini aparat desa Kalia maupun penduduk desa Kalia yang menjadi penghambat utama dalam pengelolaan alokasi dana desa, selain tingkat pendidikan aparat desa Kalia yang masih rendah faktor kesadaran/kemauan aparat desa juga masih kurangnya terhadapat tanggungjawab masingmasing aparat desa Kalia dalam pelaksanaan tugasnya masing-masing dan kendala lainya seperti pengawasan dari tingkat kabupaten/kecamatan masih kurang.

Sehingga kedepannya dibutuhkan bimbingan kepada aparat desa Kalia secara maksimal dari pemerintah kecamatan maupun kabupaten untuk memberikan pendidikan dan pelatihan terhadap aparat desa Kalia dalam pengelolaan alokasi dana desa sehingga aparat desa Kalia mengetahui segala sesuatunya yang berkaitan dengan pengelolaan alokasi dana desa untuk pembangunan desa dan pemberdayaan masyarakat desa. Untuk lebih meningkatkan kemampuan aparat desa dalam pengelolaan alokasi dana desa, aparat desa Kalia hendaknya lebih peningkatan kemampuan dalam pengelolaan alokasi dana desa baik dukungan berupa bimbingan teknis administrasi untuk menunjang kemampuan teknis (mengoperasikan komputer) agar mempercepat pembuatan persyaratan pencairan alokasi dana desa, maupun kemampuan memahami petunjuk peraturan undang-undang yang mendukung aparatur desa dalam pengelolaan alokasi dana desa untuk pengawasan dan pengendalian dan aparat desa hendaknya melibatkan elemen masyarakat dan kelompok masyarakat serta tokoh masyarakat 
yang ada didesa dalam membuat perencanaan pembangunan desa sehingga sasaran dari pembangunan sesuai dengan keinginan masyarakat.

\section{DAFTAR RUJUKAN}

Gafur, M. Z. A. (2011). In-konsistensi penerapan good governance dalam implementasi kebijakan alokasi dana desa (studi di Desa Marasipno Kecamatan Maba Tengah Kabupaten Halmahera Timur). Tesis, Universitas Gadjah Mada, Yogyakarta.

Mahfudz. (2009). Analisis dampak alokasi dana desa terhadap pemberdayaan masyarakat dan kelembagaan desa. Jurnal Organisasi dan Manajemen, 5(1), 10-22.

Munir. 2007. Manajemen Pelayanan Umum di Indonesia. Yogyakarta: Bumi Aksara.

Mustakim, Z. M. (2015). Kepemimpinan Desa. Jakarta Pusat: Kementrian Desa, Pembangunan Daerah Tertinggal, dan Transmigrasi Republik Indonesia.

Peraturan Bupati Tojo Una-Una Nomor 2 Tahun 2014 tentang Pedoman Umum dan Petunjuk Teknis Pelaksanaan Alokasi Dana Desa.

Rahman, F. (2012). Desentralisasi fiskal dan minimnya pembangunan di Indonesia. Jurnal AKP, 1(2), 103-114.

Republik Indonesia. Peraturan Menteri Dalam Negeri Nomor 113 Tahun 2014 Tentang Pengelolaan Keuangan Desa.

Peraturan Pemerintah Republik Indonesia Nomor 47 Tahun 2015 Perubahan Atas Peraturan Pemerintah Nomor 43 Tahun 2014 Tentang Peraturan Pelaksanaan Undangundang Nomor 6 Tahun 2014 Tentang Desa. Nomor 60 Tahun 2014 Tentang Dana Desa. Nomor 114 Tahun 2014 Tentang Pedoman Pembangunan Desa

Republik Indonesia. Undang-Undang Nomor 6 Tahun 2014 tentang Desa.

Robbins, S. P. (2009). Perilaku Organisasi. Edisi Lengkap. Jakarta: PT Indeks Kelompok Gramedia 2009. Teori dan Pengukuran Pengetahuan, Sikap dan Perilaku Manusia. Yogyakarta: Nuha Medika.

Setyoko, P. I. (2011). Akuntabilitas administrasi keuangan program Alokasi Dana Desa (ADD). Jurnal Ilmu Administrasi Negara, 11(1), 14-24.

Silalahi, U. (2009). Studi Tentang Ilmu Administrasi, Konsep, Teori dan Dimensi. Bandung: Sinar Baru Algensindo.

Sinungan. (2003). Desa Dan Pembangunan Desa. Jakarta: PT Sinar Mas.

Sutopo, H. B. (2006). Metodologi Penelitian Kualitatif: Dasar Teori dan Penerapannya dalam Penelitian. Surakarta: UNS

Widjaja. (2001). Pemerintahan Desa berdasarkan Undang-undang Nomor 22 Tahun 1999 Tentang Pemerintahan Daerah. Jakarta: PT Raja Grafindo Persada. (2006). Administrasi Kepegawaian. Jakarta: PT Raja Grafindo Persada. 